\title{
The relationship between Polycystic ovary syndrome and vitamin D levels
}

\section{Polikistik over sendromu ve D vitamini düzeyleri arasındaki ilişki}

\author{
Setenay Arzu Yılmazi, Sündüz Özlem Altınkaya², Ayşegül Kebabçılarle Özlem Seçilmiş Kerimoğlu1, \\ Aybike Tazegül Pekin 1 , Sedat Abuşoğlư3 ${ }^{3}$, Çetin Çelik1, Ali Ünlü3 \\ 1Selçuk University Faculty of Medicine, Department of Obstetrics and Gynecology, Konya, Turkey \\ 2 Adnan Menderes University Faculty of Medicine, Department of Obstetrics and Gynecology, Aydın, Turkey \\ ${ }^{3}$ Selçuk University Faculty of Medicine, Department of Biochemistry, Konya, Turkey
}

\begin{abstract}
Objective: The main aim of this study was to determine the association of serum 25-hydroxyvitamin D (25-OH D) levels with hormonal, clinical and metabolic profile in patients with and without Polycystic ovary syndrome (PCOS).

Materials and Methods: Forty-eight normal-weight (body mass index (BMI) of 19-24.99 kg/m²) women with PCOS, 36 overweight (BMI of $25-29.9$ $\mathrm{kg} / \mathrm{m}^{2}$ ) women with PCOS and 56 normal-weight controls participated in the study. Blood samples were collected in the early follicular phase (between day 2 and day 5 of the menstrual cycle) at 9:00 am after an overnight fast. Circulating concentrations of 25-OH D, luteinizing hormone (LH), follicle stimulating hormone (FSH), prolactin, TSH, free testosterone, dehydroepiandrosterone sulphate (DHEA-SO4), 17-hydroxyprogesterone, sex hormonebinding globulin (SHBG), fasting insulin, fasting glucose, and lipid profile were assessed.

Results: Normal weight (BMI 19-24.99 kg/m²) and overweight (BMI 25-29.99 kg/m²) women with PCOS were compared with normal-weight controls and lower 25-OH D levels were found in both PCOS groups ( $\mathrm{p}<0.05$ and $\mathrm{p}<0.01$, respectively $25-\mathrm{OH} \mathrm{D}$ significantly negatively correlated with waist circumference (WC), waist-to-hip ratio (WHR), free testosterone and modified Ferriman-Gallwey scores, however, there was a positive correlation between 25-OH D and SHBG levels ( $\mathrm{p}<0.05)$.
\end{abstract}

Conclusion: Our findings suggest that PCOS is associated with hypovitaminosis D. J Turk Soc Obstet Gynecol 2015;1:18-24

Key Words: Vitamin D, Polycystic ovary syndrome, insulin resistance

Conflicts of Interest: The authors reported no conflict of interest related to this article.

Özet

Amaç: Bu çalışmadaki esas amacımız Polikistik over sendromu (PCOS) olan ve olmayan hastalarda, serum 25 hidroksi vitamin D (25-OH D) düzeyi ile klinik, metabolik ve hormonal parametreler arasındaki ilişkiyi araştırmaktır.

Gereç ve Yöntemler: Hastalar: 48 normal kilolu (vücut kitle index (VKİ) 19-24,99 kg/m²), 36 fazla kilolu (VKİ: 25-29,99 kg/m²) yeni tanısı konulmuş PCOS'lu hasta ve 56 sağlıklı kontrol hastası (VKİ: 19-24,99 kg/m²) çalışmaya dahil edildi. Adetin 2. ile 5. günü arasında 10-12 saatlik açlık sonrası sabah 09:00'da kan örnekleri alındı. Serum 25 hidroksi vitamin D (25-OH D), FSH, LH, E2, serbest testesteron (st), prolaktin, TSH, 17-OH progesteron, seks hormon bağlayıcı globulin (SHBG), açlık insulin, açlık glukoz, ve lipid profili değerlendirildi.

Bulgular: 25-OH D düzeyi normal ve kilolu PCOS'lu hastalarda da kontrol grubuna göre istatistiksel olarak anlamlı düşük düzeylerde bulundu (p<0,05, p<0,01 sırası ile). 25-OH D düzeyi ile bel çevresi, bel kalça oranı, serbest testesteron, modifiye Ferriman Galwey skoru arasında istatistiksel olarak anlamlı negatif korelasyon; SHBG ile pozitif korelasyon saptandı.

Sonuç: PCOS, D vitamini eksikliği ile ilişkilidir. J Turk Soc Obstet Gynecol 2015;1:18-24

Anahtar Kelimeler: D vitamini, Polikistik over sendromu, insülin rezistansı

Çıkar Çatışması: Yazarlar bu makale ile ilgili olarak herhangi bir çıkar çatışması bildirmemiştir. 


\section{Introduction}

Polycystic ovary syndrome (PCOS) is an endocrine disease characterized by hyperandrogenism, anovulation and hyperinsulinemia. It is frequently encountered in women in their reproductive period(1). It has been reported to have a prevalence of 6-12\%(2). It may also create long-term health risks, such as type 2 diabetes, endometrial cancer and cardiovascular disease as it is associated with anovulation, hyperinsulinemia and central obesity $(3,4)$. At present, the etiopathogenesis and diagnostic criteria of PCOS are debatable.

Vitamin D has important roles in various parts of the body, especially in the bones. The active form of vitamin $\mathrm{D}$ plays an important role in bone metabolism, regulation of calcium-phosphorus equilibrium and cell differentiation and proliferation $(5,6)$. Vitamin D deficiency is quite common in the general population. In fact, in several studies, vitamin D levels were found to be below $20 \mathrm{ng} / \mathrm{ml}$ in $10-60 \%$ of adults $(7,8)$. Serum 25-hydroxy vitamin D (25-OH D) concentrations of below $20 \mathrm{ng} / \mathrm{ml}$ are considered as vitamin D deficiency and serum 25-OH D concentrations of 20-30 ng/ml are considered as vitamin D insufficiency ${ }^{(9)}$.

1.25-OH D increases insulin synthesis and secretion(10) and regulates steroidogenesis in the human ovarian tissue(11). In addition, genetic PCOS related with vitamin D receptor variances have been described(12). In the light of this information, there is a debate about whether vitamin $\mathrm{D}$ deficiency plays a role in PCOS pathogenesis or it is a result of PCOS.

The underlying pathogenesis of PCOS are insulin resistance and compensatory hyperinsulinemia(13). Increased insulin resistance causes an increase in weight which triggers hyperandrogenism and, thus, results in clinical symptoms. Although insulin resistance more frequently appears in obese patients (65\%), it is less frequent in lean patients with PCOS $(20 \%)(14)$.

Studies comparing vitamin D levels between patients with PCOS and healthy women with normal ovulation have yielded conflicting results. Some studies have shown that vitamin D levels do not change in patients with $\operatorname{PCOS}(15,16)$, while others have reported higher levels(17) or low levels $(18,19)$ of vitamin D. It has been found that body mass index (BMI) and insulin resistance negatively correlated with vitamin D levels and obese patients have been reported to have low levels of vitamin $\mathrm{D}(15,18,20,21)$. One study revealed that insulin resistance was not correlated with vitamin $\mathrm{D}$ and that obesity was associated with low vitamin D levels(22). In a study on obese patients with PCOS by Palm et al. in 2012, insulin resistance parameters did not change after three-month supplementation of vitamin D while total testosterone and androstenedion levels decreased(23). The aim of this study was to investigate whether there was a relationship of vitamin D levels with insulin resistance, BMI and metabolic parameters in patients with PCOS and healthy women with normal ovulation.

\section{Materials and Methods}

Ethical approval was obtained from the Ethics Committee of Selçuk University Faculty of Medicine. It was conducted in two centers: Selçuk University Faculty of Medicine, Konya, and Adnan Menderes University Faculty of Medicine, Aydın. The participants consisted of 48 normal-weight patients with PCOS (BMI of $19-24.99 \mathrm{~kg} / \mathrm{m}^{2}$ ), 36 overweight patients with PCOS (BMI of $25-29.99 \mathrm{~kg} / \mathrm{m}^{2}$ ) and 56 healthy controls aged 18-40 years who attended the gynecology outpatient clinics in both centers. The diagnosis of PCOS was based on the presence of two out of three 2003 Rotterdam ESHRE/ASRM diagnostic criteria, i.e. 1- Oligo-anovulation (having menstruation at longer than 35 day intervals) 2- Clinical picture of hirsutism, acne and biochemical hyperandrogenism, and 3-polycystic ovaries on ultrasonography (ovarian volume of over $10 \mathrm{~cm}^{3}$ or presence of more than 12 follicles of 2-9 $\mathrm{mm}$ in length)(24). Clinical hyperandrogenism was evaluated with the modified Ferriman-Gallwey (mFG) scores and having a score of over 8 was considered hirsutism. This scoring system is used to evaluate the distribution of hair on nine different parts of the body on a scale ranging from 0 to 4 (upper lip, chin, chest, lower and upper parts of the back, lower and upper abdomen, upper parts of arms and legs)(25). Height, weight, hip and waist measurements were made in all patients. Waist circumference (WC) was measured over the umbilicus, hip circumference was measured over the distance between greater trochanters and the results were expressed in $\mathrm{cm}$. Waist to hip ratio was calculated by dividing waist circumference by hip circumference and BMI was calculated by dividing weight (in kg) by height (in meters) squared. The women presenting to the infertility outpatient clinics of both centers, having BMI of $19-24.99 \mathrm{~kg} / \mathrm{m}^{2}$ and not having symptoms of anovulation and hyperandrogenism were included in the control group. Out of the patients having PCOS, those with BMI of $19-24.99 \mathrm{~kg} / \mathrm{m}^{2}$ were considered as normal weight women and those with BMI of $25-29.99 \mathrm{~kg} / \mathrm{m}^{2}$ were considered as overweight women. Women having congenital adrenal hyperplasia, Cushing's syndrome and androgen releasing tumors which cause a similar physical appearance, and systemic diseases like diabetes mellitus, using medications which affect carbohydrate and calcium metabolisms and taking hormones within the three months prior to the study were not included in the study. Blood specimens were obtained between 8 am and 9 am on the $2^{\text {nd }}-5$ th days of menstrual bleeding after 10-12 hours fasting for FSH, LH, E2, free testosterone (ft), prolactin, TSH, 17-OH progesteron, sex hormone binding globulin, fasting glucose, fasting insulin and lipid profile. Within two hours after these tests were performed, the remaining sera were centrifuged and kept at $-40{ }^{\circ} \mathrm{C}$ to determine $25-\mathrm{OH} \mathrm{D}$ levels. Insulin resistance index (homeostasis model assessmentinsulin resistance, HOMA-IR) was calculated by using the following formula: Insulin resistance=fasting glucose $(\mathrm{mg} / \mathrm{dl}) \mathrm{x}$ fasting insulin $(\mu \mathrm{U} / \mathrm{mL}) / 405)(26)$. 25-OH D analyses were made with a liquid chromatography mass spectrometer (LC-MS/MS) 
in the biochemistry laboratory of Selçuk University. In 25-OH D measurement with liquid chromatography-tandem mass spectrometer, linearity was $100 \%$ for $240 \mathrm{ng} / \mathrm{mL}$ and $94 \%$ for $7.5 \mathrm{ng} / \mathrm{mL}$, intraday assay precision was $5 \%$ and inter day assay precision was $6.7 \%$ and obtained substance concentration in $\mathrm{ng} / \mathrm{mL}$ was around $94-98 \%$.

\section{Statistical Analyses}

Data were analyzed with SPSS v.18.0 for Windows. The Kolmogorov-Smirnov test was used to determine whether continuous and discrete variables were distributed normally and the Levene's test was used to determine whether variances were homogenous. Results of descriptive statistical analyses were expressed in mean \pm standard deviation or median (minimum-maximum). Student's t-test was used to determine whether differences in mean values between the groups were significant since there were two independent groups and one way variance analysis (One-way ANOVA) was used to determine significance of differences between more than two groups. The Mann-Whitney $U$ test was used to evaluate significance of differences in median values between two independent groups and the Kruskal-Wallis test was used for the evaluation of differences between more than two groups. When the results of the Kruskal-Wallis test and one-way analysis of variance were significant, Tukey's HSD post-hoc test or Conover's nonparametric multiple comparisons test was used to determine the reasons of differences. Spearman's correlation test was utilized to show whether there was a significant correlation between continuous and discrete variables. Multiple variables linear regression analysis was used to show whether there was still a difference in vitamin D levels between PCOS and control groups after confounding factors were adjusted. All variables found to have a significance level of $\mathrm{p}<0.10$ in one variable statistical analysis were included into the multiple variable model $(27,28)$. Regression coefficient, $95 \%$ confidence interval and $t$ statistics were calculated for each variable. Since vitamin D levels were not distributed normally, logarithmic conversion was made in regression analyses. A p value of less than 0.05 was considered statistically significant.

\section{Results}

Table 1 presents clinical, hormonal and biochemical features of the healthy controls, the normal weight women and the overweight women. 25-OH D levels were significantly low in both the normal weight women with PCOS and the overweight women with PCOS compared to the control group $(\mathrm{p}<0.05$, $\mathrm{p}<0.01$, respectively). Although the 25-OH D levels were lower in the overweight women with PCOS than the normal weight women with PCOS, the difference was not significant.

Considering that the cut-off value for vitamin D deficiency is 20 $\mathrm{ng} / \mathrm{ml}, 33$ healthy controls (58.9\%) and 72 patients with PCOS (85.7\%) had vitamin D deficiency.

Table 2 shows the correlations between vitamin D and clinical, biochemical and hormonal features. There was a significant negative correlation between vitamin D and WC, WHR, ft and $\mathrm{mFG}$ scores and a positive correlation between vitamin $\mathrm{D}$ and sex hormone-binding globulin (SHBG). Vitamin D was not correlated with other parameters.

Table 3 and Table 4 present the results of multiple linear regression analyses performed after all factors affecting vitamin $\mathrm{D}$ were adjusted. When WC, $\mathrm{mFG}$, ft and SHBG, found to have a significant correlation with vitamin $\mathrm{D}$ in single factor analyses, and LH, DHEAS and HDL cholesterol, thought to be significant in regression analyses, were adjusted, 25-OH D levels were significantly low in all the patients with PCOS $(B=-0.557$ 95\%CI: $-0.841--0.274$ and $\mathrm{p}<0.001)$ and the normal weight women with PCOS $(\mathrm{B}=-0.528$ 95\%CI: $-0.810--0.245$ and $\mathrm{p}<0.001)$ and the overweight women with PCOS $(\mathrm{B}=-0.788$ 95\%CI: $-1.160--0.417$ and $\mathrm{p}<0.001)$ compared to the controls.

\section{Discussion}

PCOS is a syndrome associated with increased ovarian and adrenal androgen secretions and hyperandrogenism and resultant hirsutism, hyperinsulinemia and central obesity. Although vitamin D primarily plays a role in bone metabolism, it has important functions in the reproductive system. Vitamin $\mathrm{D}$ receptors are found in ovarian and endometrial tissues and play an important role in steroidogenesis(29). Vitamin D deficiency is more frequently encountered in patients with type 2 diabetes(30) and an inverse relationship between vitamin D and BMI has been shown in several studies $(31,32)$. The present study was directed towards investigating the role of vitamin D in physiopathology of PCOS and the relationship between vitamin D levels and clinical and metabolic features.

Consistent with prior studies comparing healthy controls and patients with $\operatorname{PCOS}(18,19)$, this study showed that $25-\mathrm{OH} \mathrm{D}$ levels were lower in both in the overweight and normal weight women with PCOS than in the normal weight healthy controls. 25(OH)D3 levels were lower in the overweight women with PCOS than in the normal weight women with PCOS, though the difference was not significant. In a study by Panadis et al., there was not a difference in vitamin $\mathrm{D}$ levels between healthy individuals and patients with PCOS in general, but obese patients with PCOS had lower vitamin D levels(16).

A large amount of vitamin $D$ is synthesized in the skin under the influence of sunlight. Although obese patients have a larger skin surface exposed to sunlight, they more frequently have vitamin D deficiency. Sedentary life style, fat soluble feature of vitamin D, storage of vitamin D in fat tissue and decreased bioactivity of vitamin $\mathrm{D}$ are mechanisms used to explain vitamin D deficiency(33).

Decreased vitamin D levels in patients with PCOS have been attributed to only insulin resistance(15) or obesity(22) in some studies or both insulin resistance and obesity in other studies $(20,21)$. However, in the current study, independent from BMI and insulin resistance in the patients with PCOS, vitamin D levels were found to be low which is consistent with the results 
of a study by Mazloomiet al.(19). Independent from other risk factors, PCOS itself was found to be associated with decreased vitamin D levels.

The most important indicator of hyperandrogenism, a diagnostic criterion for PCOS, is hirsutism or increased androgen levels in biochemical analyses. The present study revealed a negative correlation between vitamin $\mathrm{D}$ and $\mathrm{mFG}$ scores and positive correlation between vitamin D and SHBG which is compatible with the results of two prior studies(20,34). Hahn et al. and Wehr et al. found no correlation between vitamin D and other androgenic parameters and reported that the relationship between vitamin D and SHBG levels depends on obesity and that there was no correlation between vitamin D and SHBG after BMI was corrected. SHBG levels directly influence the activity of peripheral androgen and are biologically associated with active testosterone levels. Ylddızhan et al. noted that there was a negative correlation between total testosterone and vitamin D in both obese and non-obese women but this correlation resulted from a decrease in SHBG levels caused by obesity(21). This may occur through various mechanisms. Lower rates of exposure to sunlight for cosmetic reasons in patients with hirsutism can be one of the mechanisms explaining vitamin $\mathrm{D}$ deficiency. These findings suggest that vitamin D supplements can have an effect in patients with PCOS, especially in those with clinical hyperandrogenism. There have been few studies on the effect of vitamin D supplements on hyperandrogenism. In two previous studies, androgen levels did not decrease after vitamin $\mathrm{D}$ was given $(35,36)$. In a study by Palm et al. in 2012, administration of vitamin D supplements for three months reduced total testosterone and androstenedion levels but did not change

Table 1. Clinical, hormonal and biochemical features of the controls, the normal weight women with polycystic ovary syndrome (PCOS) and the overweight women with PCOS

\begin{tabular}{|c|c|c|c|c|}
\hline & $\begin{array}{l}\text { Normal weight } \\
\text { women with PCOS } \\
(n=48)\end{array}$ & $\begin{array}{l}\text { Overweight women } \\
\text { with PCOS } \\
(n=36)\end{array}$ & $\begin{array}{l}\text { Controls } \\
(n=56)\end{array}$ & $\mathrm{p}$ \\
\hline Age $(\mathrm{yr})^{\dagger}$ & $22.6 \pm 2.9$ & $22.5 \pm 4.2$ & $23.5 \pm 4.4$ & 0.367 \\
\hline $\mathrm{WC}(\mathrm{cm})^{\dagger}$ & $72.5 \pm 6.2^{a, c}$ & $83.4 \pm 5.8 \mathrm{~b}, \mathrm{c}$ & $69.2 \pm 5.6^{a, b}$ & $<0.001$ \\
\hline $\mathrm{HC}(\mathrm{cm})^{\dagger}$ & $92.8 \pm 5.5^{c}$ & $103.6 \pm 4.3 \mathrm{~b}, \mathrm{c}$ & $92.0 \pm 5.3 b$ & $<0.001$ \\
\hline $\mathrm{WHR}^{+}$ & $0.78 \pm 0.05^{\mathrm{a}, \mathrm{c}}$ & $0.80 \pm 0.05 b, c$ & $0.74 \pm 0.05^{a, b}$ & $<0.001$ \\
\hline Fasting glucose $(\mathrm{mg} / \mathrm{dl})^{\ddagger}$ & $87(68-119)$ & $89(74-117)$ & $89(75-109)$ & 0.468 \\
\hline Insulin $(\mathrm{mU} / \mathrm{mL})^{\ddagger}$ & $8.6(3.0-39.0) a, c$ & $11.0(4.8-31.0)^{\mathrm{b}, \mathrm{c}}$ & $7.2(1.4-34.0)^{a, b}$ & $<0.001$ \\
\hline HOMA-IR ${ }^{\ddagger}$ & $1.9(0.6-13.6)^{\mathrm{a}}$ & $2.5(1.0-6.8)^{b}$ & $1.6(0.3-9.1)^{a, b}$ & $<0.001$ \\
\hline Insulin/glucose ratio & $10.2(3.0-30.1)^{a}$ & $8.3(2.9-17.7)^{b}$ & $11.9(3.0-63.6)^{a, b}$ & $<0.001$ \\
\hline $\operatorname{HDL}(\mathrm{mg} / \mathrm{dL})^{\ddagger}$ & $49(36-77)^{c}$ & $44.5(30-67)^{b, c}$ & $51.5(34-81)^{\mathrm{b}}$ & $<0.001$ \\
\hline $\mathrm{LDL}(\mathrm{mg} / \mathrm{dL})^{\dagger}$ & $97.6 \pm 20.1$ & $101.3 \pm 22.5$ & $94.4 \pm 29.7$ & 0.424 \\
\hline $\mathrm{TG}(\mathrm{mg} / \mathrm{dL})^{\ddagger}$ & $77.5(38-189) c$ & $108.5(39-276)^{b, c}$ & $74.5(32-146)^{b}$ & 0.002 \\
\hline $\mathrm{TC}(\mathrm{mg} / \mathrm{dL})^{\dagger}$ & $163.7 \pm 27.0$ & $170.1 \pm 26.3$ & $161.9 \pm 35.6$ & 0.441 \\
\hline FSH $(\mathrm{IU} / \mathrm{L})^{\ddagger}$ & $4.8(2.3-7.4)$ & $5.1(3.0-8.0)$ & $5.1(1.3-8.5)$ & 0.173 \\
\hline $\mathrm{LH}(\mathrm{IU} / \mathrm{L})^{\ddagger}$ & $8.9(2.0-29.0)^{a}$ & $9.2(2.1-38.0)^{\mathrm{b}}$ & $5.0(0.8-11.2)^{a, b}$ & $<0.001$ \\
\hline $\mathrm{PRL}^{\ddagger}$ & $13.5(5.7-34.0)$ & $14.0(4.5-26.0)$ & $12.6(5.8-22.6)$ & 0.898 \\
\hline $\mathrm{TSH}^{+}$ & $1.9 \pm 0.81$ & $1.9 \pm 0.72$ & $1.7 \pm 0.77$ & 0.448 \\
\hline DHEA-SO $^{+}$ & $329.5 \pm 100.2^{\mathrm{a}}$ & $331.8 \pm 108.4^{b}$ & $259.4 \pm 95.7 \mathrm{a}, \mathrm{b}$ & $<0.001$ \\
\hline $\mathrm{ft}(\mathrm{pg} / \mathrm{mL})^{\ddagger}$ & $2.9(0.3-17.8)^{a, c}$ & $3.9(1.0-18.7)^{\mathrm{b}, \mathrm{c}}$ & $1.4(0.4-4.9)^{a}, \mathrm{~b}$ & $<0.001$ \\
\hline SHBG $(\mathrm{nmol} / \mathrm{l})^{\ddagger}$ & $38.7(11.1-76.1)^{a, c}$ & $28.9(17.5-94.7)^{b, c}$ & $61.3(26.0-138.0)^{a, b}$ & $<0.001$ \\
\hline $\mathrm{mFG}^{\ddagger}$ & $9(0-21)^{a}$ & $9(0-14)^{b}$ & $2(0-7)^{a, b}$ & $<0.001$ \\
\hline Vitamin D (ng/mL) $)^{\ddagger}$ & $12.4(4.1-46.7)^{a}$ & $10.1(2.5-25.0)^{\mathrm{b}}$ & $17.9(9.7-81.6)^{a, b}$ & $<0.001$ \\
\hline \multicolumn{5}{|c|}{$\begin{array}{l}\text { t: Data are expressed in mean } \pm \text { standard deviation, Data are expressed in median values (minimum-maximum). PCOS: Polycystic ovary syndrome, WC: Waist circumference, HC } \\
\text { Hip circumference, WHR: Waist to hip ratio, HOMA-IR: Homeostasis model insulin resistance, HDL: High density lipoprotein, LDL: Low density lipoprotein, TG: Triglyceride, TC } \\
\text { Total cholesterol, FSH: follicle stimulating hormone, LH: Luteinizing hormone, PRL: Prolactin, TSH: Thyroid stimulating hormone, DHEA-SO4: Dehydroepiandrosteron sulfate, ft: Free } \\
\text { testosterone, SHBG: Sex hormone binding globulin, } \mathrm{mFG:} \mathrm{Modified} \mathrm{Feriman-Galvey} \mathrm{score,} \mathrm{a:} \mathrm{The} \mathrm{difference} \mathrm{was} \mathrm{significant} \mathrm{between} \mathrm{the} \mathrm{normal} \mathrm{weight} \mathrm{women} \mathrm{with} \mathrm{PCOS} \mathrm{and} \mathrm{the} \mathrm{contro} \\
\text { group (p<0.05), b: The difference was significant between the overweight women with PCOS and the control group (p<0.01), c: The difference was significant between the normal weigh } \\
\text { women with PCOS and the overweight women with PCOS (p<0.05) }\end{array}$} \\
\hline
\end{tabular}


Table 2. Correlations between vitamin D and clinical, biochemical and hormonal features of the patients

\begin{tabular}{|c|c|c|}
\hline & $\begin{array}{l}\text { Correlation } \\
\text { coefficient }\end{array}$ & $\mathrm{p}$ \\
\hline Age (y) & -0.047 & 0.582 \\
\hline $\mathrm{WC}(\mathrm{cm})$ & -0.304 & $<0.001$ \\
\hline $\mathrm{HC}(\mathrm{cm})$ & -0.218 & 0.010 \\
\hline WHR & -0.214 & 0.011 \\
\hline Fasting glucose (mg/dl) & -0.051 & 0.550 \\
\hline Insulin (mU/mL) & -0.129 & 0.129 \\
\hline HOMA-IR & -0.135 & 0.111 \\
\hline Insulin/glucose ratio & 0.111 & 0.190 \\
\hline HDL (mg/dL) & 0.159 & 0.060 \\
\hline LDL (mg/dL) & -0.035 & 0.680 \\
\hline $\mathrm{TG}(\mathrm{mg} / \mathrm{dL})$ & -0.001 & 0.991 \\
\hline $\mathrm{TC}(\mathrm{mg} / \mathrm{dL})$ & -0.011 & 0.894 \\
\hline FSH (IU/L) & 0.029 & 0.732 \\
\hline LH (IU/L) & -0.152 & 0.073 \\
\hline PRL & 0.055 & 0.520 \\
\hline TSH & 0.049 & 0.562 \\
\hline DHEA-SO4 & -0.151 & 0.074 \\
\hline $\mathrm{ft}(\mathrm{pg} / \mathrm{mL})$ & -0.250 & 0.003 \\
\hline SHBG (nmol/l) & 0.241 & 0.004 \\
\hline $\mathrm{mFG}$ & -0.280 & $<0.001$ \\
\hline \multicolumn{3}{|c|}{$\begin{array}{l}\text { WC: Waist circumference, HC: Hip circumference, WHR: Waist to hip ratio, HOMA-IR: } \\
\text { Homeostasis model insulin resistances, HDL: High density lipoprotein, LDL: Low } \\
\text { density lipoprotein, TG: Triglyceride, TC: Total cholesterol, FSH: Follicle stimulating } \\
\text { hormone, LH: Luteinizing hormone, PRL: Prolactin, TSH: Thyroid stimulating hormone, } \\
\text { DHEA-SO4: Dehydroepiandrosteron sulfate, ft: Free testosterone, SHBG: Sex hormone } \\
\text { binding globulin, mFG: Modified Feriman-Galvey score }\end{array}$} \\
\hline
\end{tabular}

parameters of insulin resistance in obese patients with PCOS(23). Administration of vitamin D and calcium can influence ovarian and adrenal steroidogenesis, which can play a role in reduction of circulating androgen levels. Similarly, in the present study, although there was a negative correlation between vitamin $\mathrm{D}$ and $\mathrm{ft}$, vitamin $\mathrm{D}$ was not correlated with insulin resistance. Although several studies have shown a relationship between vitamin D deficiency and insulin resistance, one recent study has revealed that there was no relationship between vitamin $\mathrm{D}$ and insulin resistance when hyperinsulinemic-euglycemic clamp test, which is considered as a gold standard in peripheral insulin sensitivity, was performed the same study also stated that vitamin D deficiency did not directly affect development of insulin resistance but that the deficiency was associated with obesity(22). In addition, weight loss was reported to increase vitamin D levels in obese patients. In the current study, evaluation of peripheral insulin resistance was based on fasting glucose and insulin levels and vitamin D was not correlated with insulin resistance.

Consistent with the results of a study by Mazloomiet al. in 2012, the present study showed low levels of vitamin D independent of BMI and insulin resistance in the patients with PCOS(19). Even when other risk factors were corrected, vitamin D levels were still low. Conflicting evidence from the literature can be attributed to genetic, geographical and demographic differences between study populations and differences in study designs and methods. Therefore, prospective studies with larger samples are needed.

\section{Discussion}

Vitamin D deficiency can be an effective factor in development of PCOS and vitamin D supplementation can play a role in prevention of this condition. There have been studies suggesting that vitamin D levels are related to BMI in obese patients with PCOS and that vitamin D administration has a positive effect on clinical and biochemical symptoms. In the present study, PCOS was found to be related to vitamin D deficiency independent

Table 3. Results of multiple linear regression analyses after correction of all factors affecting vitamin D levels

\begin{tabular}{|c|c|c|c|c|c|}
\hline \multirow{3}{*}{ PCOS } & \multirow{3}{*}{$\begin{array}{l}\text { Regression } \\
\text { coefficient } \\
(\beta) \\
-0.557\end{array}$} & \multicolumn{2}{|c|}{ 95\% Confidence interval } & \multirow{2}{*}{ t-statistics } & \multirow{2}{*}{$\mathrm{p}$} \\
\hline & & Lower limit & Upper limit & & \\
\hline & & -0.841 & -0.274 & -3.889 & $<0.001$ \\
\hline WC & -0.011 & -0.022 & 0.001 & -1.774 & 0.078 \\
\hline $\mathrm{mFG}$ & 0.015 & -0.010 & 0.040 & 1.190 & 0.236 \\
\hline $\mathrm{LH}$ & 0.006 & -0.010 & 0.022 & 0.715 & 0.476 \\
\hline $\mathrm{ft}$ & -0.006 & -0.037 & 0.025 & -0.358 & 0.721 \\
\hline SHBG & -0.004 & -0.009 & 0.001 & -1.707 & 0.090 \\
\hline DHEA-SO4 & 0.000 & -0.001 & 0.001 & -0.789 & 0.432 \\
\hline HDL & 0.003 & -0.005 & 0.012 & 0.778 & 0.438 \\
\hline
\end{tabular}

WC: Waist circumference, mFG: Modified Feriman-Galvey score, LH: Luteinizing hormone, ft: Free testosterone, SHBG: Sex hormone binding globulin, DHEA-SO4: Dehydroepiandrosteron sulfate, HDL: High density lipoprotein 
Table 4. Results of multiple linear regression analyses after correction of all factors affecting vitamin D levels

\begin{tabular}{|c|c|c|c|c|c|}
\hline & & $95 \%$ Con & ence interval & & \\
\hline & $(\boldsymbol{\beta})$ & Lower limit & Upper limit & t-statistics & $\mathrm{p}$ \\
\hline Normal weight women with PCOS & -0.528 & -0.810 & -0.245 & -3.695 & $<0.001$ \\
\hline Overweight women with PCOS & -0.788 & -1.160 & -0.417 & -4.197 & $<0.001$ \\
\hline WC & -0.002 & -0.017 & 0.012 & -0.334 & 0.739 \\
\hline $\mathrm{mFG}$ & 0.012 & -0.013 & 0.038 & 0.988 & 0.325 \\
\hline LH & 0.006 & -0.009 & 0.022 & 0.808 & 0.421 \\
\hline $\mathrm{ft}$ & 0.001 & -0.030 & 0.033 & 0.088 & 0.930 \\
\hline SHBG & -0.005 & -0.009 & 0.0002 & -1.876 & 0.063 \\
\hline DHEA-SO4 & -0.0004 & -0.001 & 0.0005 & -0.871 & 0.386 \\
\hline HDL & 0.002 & -0.006 & 0.010 & 0,474 & 0.636 \\
\hline
\end{tabular}

PCOS: Polycystic ovary syndrome, WC: Waist circumference, mFG: Modified Feriman-Galvey score, LH: Luteinizing hormone, ft: Free testosterone, SHBG: Sex hormone binding globulin, DHEA-SO4: Dehydroepiandrosteron sulfate, HDL: High density lipoprotein

of BMI. Therefore, randomized studies with large samples are required to investigate the effects of vitamin D supplementation in lean patients with PCOS.

\section{References}

1. Carmina E, Lobo RA. Polycystic ovary syndrome (PCOS): arguably the most common endocrinopathy is associated with significant morbidity in women. J Clin Endocrinol Metab 1999;84:1897-9.

2. Wojciechowski P, Lipowska A, Rys P, Ewens KG, Franks S, Tan S, et al. Impact of FTOgenotypes on BMI and weight in polycystic ovary syndrome: a systematic review and meta-analysis. Diabetologia 2012;55:2636-45.

3. Wild S, Pierpoint T, Jacobs H, McKeigue P. Long-termconsequences of polycystic ovary syndrome: results of a 31 yearfollow-upstudy. Hum Fertil (Camb) 2000;3:101-5.

4. Haoula Z, Salman M, Atiomo W. Evaluating the association between endometrial cancer and polycystic ovary syndrome. Hum Reprod 2012;27:1327-31.

5. Walters MR. Newly identified actions of the vitamin D endocrine system. Endocr Rev 1992;13:719-64.

6. Studzinski GP, McLane JA, Uskokovic MR. Signaling pathways for vitamin D-induced differentiation: implications for therapy of proliferative and neoplastic diseases. Crit Rev Eukaryot Gene Expr 1993;3:279-312.

7. Prentice A. Vitamin D deficiency: a global perspective. Nutr Rev 2008;66(10Suppl 2):153-64.

8. Lips P. Worldwide status of vitamin D nutrition. J Steroid Biochem Mol Biol 2010;121:297-300.

9. Holick MF. Vitamin D deficiency. N Engl J Med 2007;357:266-81.

10. Teegarden D, Donkin SS. Vitamin D: emerging new roles in insülin sensitivity. Nutr Res Rev 2009;22:82-92.

11. Parikh G, Varadinova M, Suwandhi P, Araki T, Rosenwaks Z, Poretsky $\mathrm{L}$, et al. Vitamin D regulates steroidogenesis and insulin-like growth factor binding protein-1 (IGFBP-1) production in human ovarian cells. Horm Metab Res 2010;42:754-7.

12. Ranjzad F, Mahban A, Shemirani AI, Mahmoudi T, Vahedi M, Nikzamir A, et al. Influence of gene variants related to calcium homeostasis on biochemical parameters of women with polycystic ovary syndrome. J Assist Reprod Genet 2011;28:225-32.
13. Franks S. Polycystic ovary syndrome. N Engl J Med 1995;333:85361.

14. Dale PO, Tanbo T, Vaaler S, Abyholm T. Body weight, hyperinsulinemia, and gonadotropin levels in the polycystic ovarian syndrome: evidence of two distinct populations. Fertil Steril 1992;58:487-91.

15. Li HW, Brereton RE, Anderson RA, Wallace AM, Ho CK. Vitamin D deficiency is common and associated with metabolic risk factors in patients with polycystic ovary syndrome. Metabolism 2011;60:147581.

16. Panidis D, Balaris C, Farmakiotis D, Rousso D, Kourtis A, Balaris V, et al. Serum parathyroid hormone concentrations are in creased in women with polycystic ovary syndrome.Clin Chem 2005;51:16917.

17. Mahmoudi T, Gourabi H, Ashrafi M, Yazdi RS, Ezabadi Z. Calciotropic hormones, insülin resistance, and the polycystic ovary syndrome. Fertil Steril 2010;93:1208-14.

18. Wehr E, Trummer O, Giuliani A, Gruber HJ, Pieber TR, ObermayerPietsch B. Vitamin D-associated polymorphisms are related to insülin resistance and vitamin $\mathrm{D}$ deficiency in polycystic ovary syndrome. Eur J Endocrinol 2011;164:741-9.

19. Mazloomi S, Sharifi F, Hajihosseini R, Kalantari S, Mazloomzadeh S. Association between Hypoadiponectinemia and Low Serum Concentrations of Calcium and Vitamin D in Women with Polycystic Ovary Syndrome. ISRN Endocrinol 2012;2012:949427.

20. Hahn S, Haselhorst U, Tan S, Quadbeck B, Schmidt M, Roesler S, et al. Low serum 25-hydroxyvitamin D concentrations are associated with insülin resistance and obesity in women with polycystic ovary syndrome. Exp Clin Endocrinol Diabetes 2006;114:577-83.

21. Yildizhan R, Kurdoglu M, Adali E, Kolusari A, Yildizhan B, Sahin HG, et al. Serum 25-hydroxyvitamin D concentrations in obese and onobese women with polycystic ovary syndrome. Arch Gynecol Obstet 2009;280:559-63.

22. Muscogiuri G, Policola C, Prioletta A, Sorice G, Mezza T, Lassandro A, et al. Low levels of 25(OH) D and insulin-resistance: 2 unrelated features or a cause-effect in PCOS? Clin Nutr 2012;31:476-80.

23. Pal L, Berry A, Coraluzzi L, Kustan E, Danton C, Shaw J, et al. Therapeutic implications of vitamin D and calcium in overweight women with polycystic ovary syndrome. Gynecol Endocrinol 2012;28:965-8. 
24. Rotterdam ESHRE/ASRM-Sponsored PCOS consensus workshop group. Revised 2003 consensus on diagnostic criteria and long-term health risks related to polycystic ovary syndrome (PCOS). Hum Reprod 2004;19:41-7.

25. Wild RA, Vesely S, BeebeL,WhitsettT, OwenW. Ferriman Gallwey self scoring I: performance assessment in women with polycystic ovary syndrome. J Clin Endocrinol Metab2005;90:4112-4.

26. Legro RS, Castracane VD, Kauffman RP. Detecting insülin resistance in polycystic ovary syndrome: purposes and pitfalls. Obstet Gynecol Surv 2004;59:141-54.

27. Reha A. Uygulamalı Çok Değişkenli İstatistiksel Yöntemlere Giriş 1. Bölüm 7. Çoklu Doğrusal Regresyon, Çoklu Doğrusal Regresyon Modellerinde Değişken Seçimi. Nobel Yayın Dağıtım, Ankara, 2003:346.

28. Vittinghoff E, Glidden DV, Shiboski SC, McCulloch CE. Regression Methods in Biostatistics. Linear, Logistic, Survival and Repeated Measures Models. Chapter 5. Predictor Selection, Number of Predictors. Springer Science+Business Media, Inc. New York, 2005:149.

29. Stumpf WE, Denny ME. Vitamin D (soltriol), light, andreproduction. Am J Obstet Gynecol 1989;161:1375-84.

30. Isaia $G$, Giorgino R, Adami S. High prevalence of hypovitaminosis D in female type 2 diabetic population. Diabetes Care 2001;24:1496.

31. Holecki M, Zahorska-Markiewicz B, Janowska J, Mizia-Stec K, Zak-
Gotab A,Olszanecka-Glinianowicz M, et al. Osteoprotegerin--does it play a protective role in thepathogenesis of bone loss in obese perimenopausal women? Endokrynol Pol 2007;58:7-10.

32. Yanoff LB, Parikh SJ, Spitalnik A, Denkinger B, Sebring NG, Slaughter $\mathrm{P}$, et al. The prevalence of hypovitaminosis D and second ary hyperparathyroidism in obese Black Americans. ClinEndocrinol 2006;64:523-9.

33. Compston JE, Vedi S, Ledger JE, Webb A, Gazet JC, Pilkington TR. Vitamin D status and bone histomorphometry in gross obesity. Am J Clin Nutr 1981;34:2359-63.

34. Wehr E, Pilz S, Schweighofer N, Giuliani A, Kopera D, Pieber TR, et al. Association of hypo vitaminosis D with metabolic disturbances in polycystic ovary syndrome. Eur J Endocrinol 2009;161:575-82.

35. Selimoglu H, Duran C, Kiyici S, Ersoy C, Guclu M, Ozkaya G, et al. The effect of vitamin D replacement therapy on insülin resistance and androgen levels in women with polycystic ovary syndrome. J Endocrinol Invest 2010;33:234-8.

36. Wehr E, Pieber TR, Obermayer-Pietsch B. Effect of vitamin D3 treatment onglucose metabolism and menstrual frequency in polycystic ovary syndrome women: a pilot study. J Endocrinol Invest 2011;34:757-63. 